\title{
Supporting information of "Direct observations of organic aerosols in wintertime hazes in North China: insights into their size, shape, mixing state, and source"
}

\author{
S. R. Chen ${ }^{1}$, L. Xu ${ }^{1}$, Y. X. Zhang ${ }^{1}$, B. Chen ${ }^{1}$, X. F. Wang ${ }^{1}$, X. Y. Zhang ${ }^{2}$, M. \\ Zheng $^{3}$, J. M. Chen ${ }^{1}$, W. X. Wang ${ }^{1}$, Y. L. Sun ${ }^{4}$, P. Q. Fu ${ }^{4}$, Z. F. Wang ${ }^{4}$, W. J. Li ${ }^{1, *}$ \\ [1] Environment Research Institute, Shandong University, Jinan, Shandong 250100, \\ China \\ [2] Key Laboratory of Atmospheric Chemistry, Chinese Academy of Meteorological \\ Sciences, Beijing 100081, China \\ [3] State Key Joint Laboratory of Environmental Simulation and Pollution Control, \\ College of Environmental Sciences and Engineering, Peking University, Beijing \\ 100871, China \\ [4] State Key Laboratory of Atmospheric Boundary Layer Physics and Atmospheric \\ Chemistry, Institute of Atmospheric Physics, Chinese Academy of Sciences, Beijing, \\ China \\ *Corresponding Email: liweijun@sdu.edu.cn (W. J. Li)
}




\section{The statistics about air quality during the whole winter of 2014 in NCP}

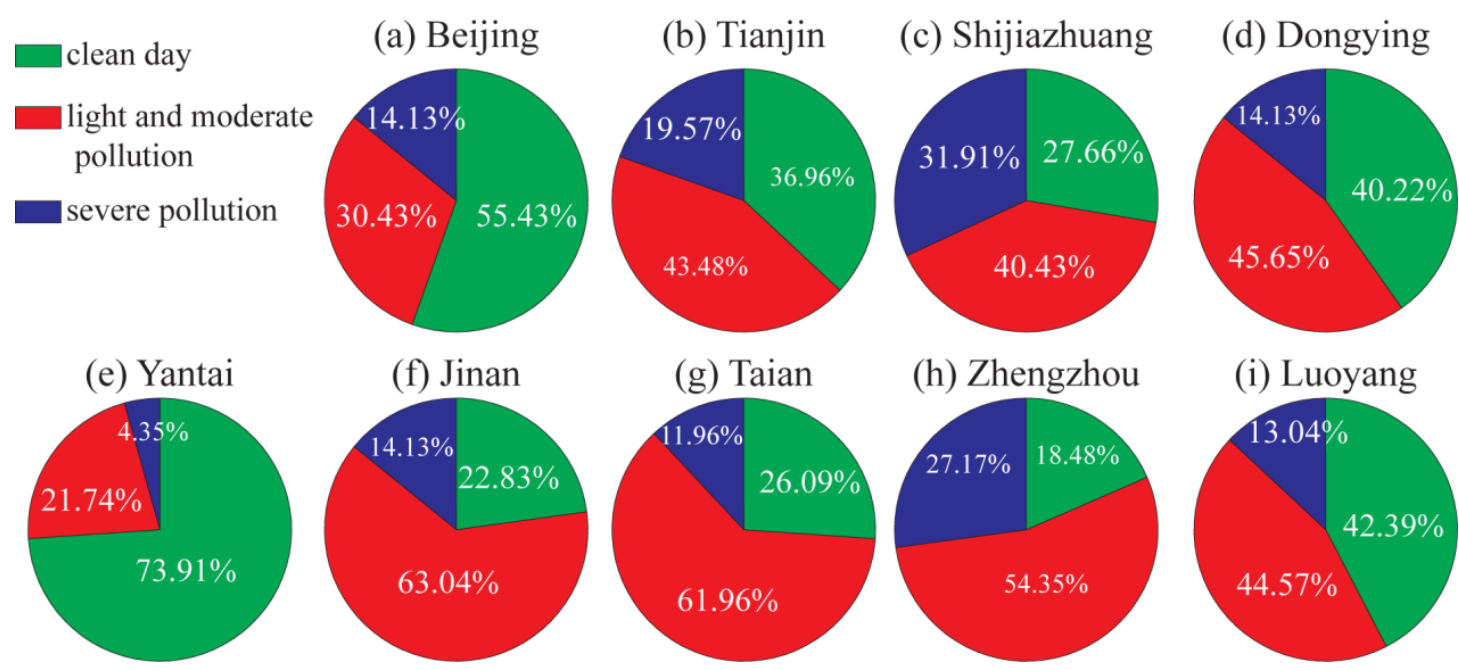

Figure S1. The statistics about air quality during the whole winter ( 92 days) of 2014-2015 in nine representative cities in the NCP. Green color represents clean day $\left(\mathrm{PM}_{2.5}<75 \mu \mathrm{g} \mathrm{m}^{-3}\right)$, red color represents light and moderate pollution $\left(75 \sim 250 \mu \mathrm{g} \mathrm{m}^{-3}\right)$ and blue color represents severe pollution $\left(\mathrm{PM}_{2.5}>250 \mu \mathrm{g} \mathrm{m}^{-3}\right)$. The light and moderate haze day account for $30-63 \%$ but the severe haze days is only about $4-32 \%$ in NCP.

\section{The relationship between EVD and ECD obtained by AFM}

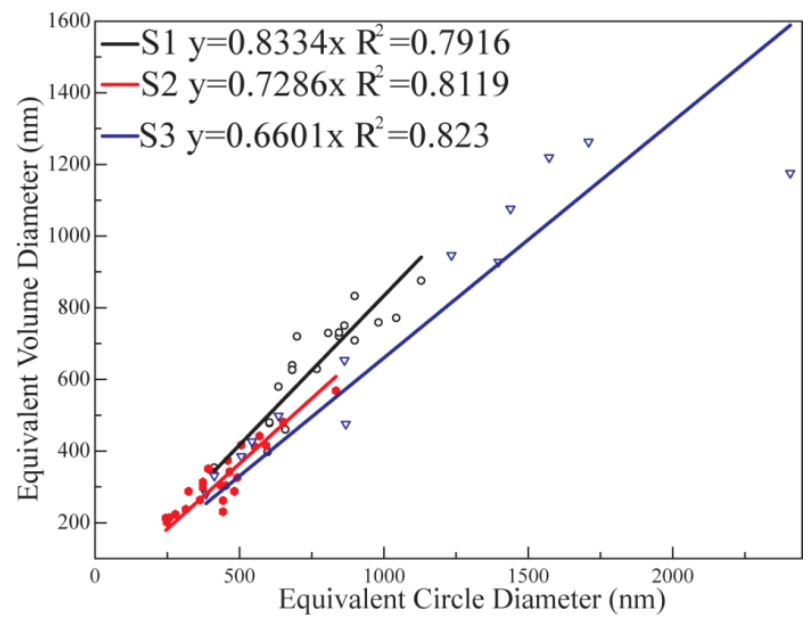

Figure S2. The correlation of equivalent circle diameter $(\mathrm{ECD}, \mathrm{x})$ and equivalent volume diameter (EVD, y) at three sampling sites obtained by AFM.

\section{The daily average $\mathbf{P M}_{2.5}$ mass concentration during sampling period}




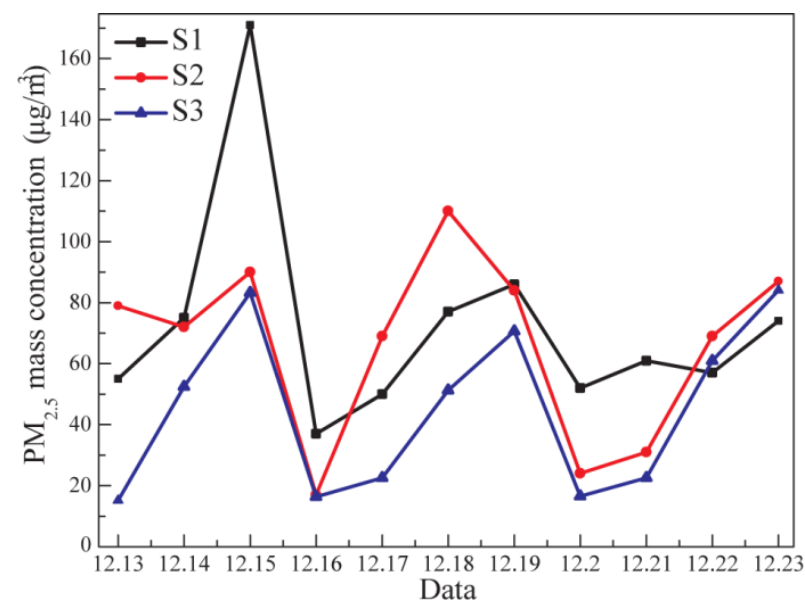

Figure S3. The series daily average $\mathrm{PM}_{2.5}$ mass concentration at three sampling sites in 13-23 December, 2014. We can see three haze events occurred on 14-15, 18-19, 23 December.

$4 \quad$ RH at three sampling sites in winter, 2014

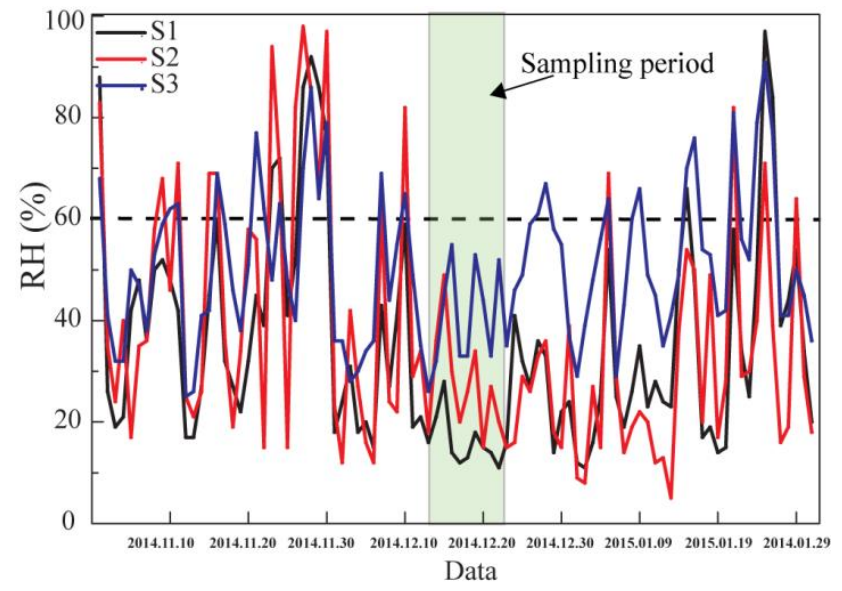

Figure S4. RH at three sampling sites in winter, 2014. We can see that the daily average RH during whole wintertime in NCP were at a low-level. Especially during the sampling period, lower than $60 \%$.

\section{Information about samples}

Table S1. Average concentrations of aerosol particles and various trace gases during haze and clean periods at three sampling sites. 


\begin{tabular}{|c|c|c|c|c|c|c|c|c|c|c|c|c|}
\hline $\mathrm{e}$ & $\begin{array}{l}\text { Air } \\
\text { Qualit } \\
\text { y }\end{array}$ & $\begin{array}{l}\mathrm{OC} \\
(\mathrm{ug} / \mathrm{m} \\
\left.{ }^{3}\right)\end{array}$ & $\begin{array}{l}\text { EC } \\
\text { (ug/m } \\
\left.{ }^{3}\right)\end{array}$ & $\begin{array}{r}\mathrm{PM}_{2.5} \\
(\mathrm{ug} / \mathrm{m} \\
\left.{ }^{3}\right)\end{array}$ & $\begin{array}{c}\text { Water-solub } \\
\text { le Ions } \\
\text { (ug/m }{ }^{3} \text { ) }\end{array}$ & $\begin{array}{c}\mathrm{OC} / \mathrm{E} \\
\mathrm{C}\end{array}$ & $\begin{array}{c}\mathrm{TC} / \mathrm{PM}_{2} \\
.5\end{array}$ & $\begin{array}{l}\text { Water-solub } \\
\text { le } \\
\text { Ions/ } / \mathrm{PM}_{2.5}\end{array}$ & $\begin{array}{l}\mathrm{SO}_{2} \\
(\mathrm{ppb} \\
\text { ) }\end{array}$ & $\begin{array}{l}\text { CO } \\
\text { (ppm } \\
\text { ) }\end{array}$ & $\begin{array}{c}\mathrm{NO} \\
2 \\
(\mathrm{ppb} \\
\text { ) }\end{array}$ & $\begin{array}{l}\mathrm{O} 3 \\
\text { (ppb } \\
\text { ) }\end{array}$ \\
\hline \multirow{2}{*}{ S1 } & $\begin{array}{l}\text { Clean } \\
\text { day }\end{array}$ & 12.2 & 2.5 & 60 & 28.1 & 4.87 & 0.24 & 0.47 & $\begin{array}{c}32.5 \\
6\end{array}$ & 0.8 & 26.1 & 23.5 \\
\hline & $\begin{array}{l}\text { Haze } \\
\text { day }\end{array}$ & 22.1 & 4.1 & 96.6 & 50.2 & 5.52 & 0.27 & 0.52 & 33.7 & 0.96 & 29.9 & 22.8 \\
\hline \multirow{2}{*}{ S2 } & $\begin{array}{l}\text { Clean } \\
\text { day }\end{array}$ & 4.4 & 0.8 & 48.2 & 14.9 & 5.07 & 0.14 & 0.31 & 21.8 & 1.1 & 24.2 & 32.1 \\
\hline & $\begin{array}{l}\text { Haze } \\
\text { day }\end{array}$ & 9.8 & 1.5 & 88.6 & 34.5 & 6.75 & 0.15 & 0.39 & 28.8 & 1.5 & 33.9 & 25.8 \\
\hline \multirow{2}{*}{ S3 } & $\begin{array}{l}\text { Clean } \\
\text { day }\end{array}$ & & & 32.3 & & & & & 14.5 & 0.7 & 17.0 & 24.7 \\
\hline & $\begin{array}{l}\text { Haze } \\
\text { day }\end{array}$ & & & 80.3 & & & & & 21.8 & 1.3 & 29.1 & 20.7 \\
\hline
\end{tabular}

From Table S1, we found that the average concentrations of OC, EC, OC/EC and water-soluble ions are much higher during haze periods than those on clear days. For example, at S2, total carbon (TC) and water-soluble ions accounting for an average of $15 \%$ and $39 \%$ of $\mathrm{PM}_{2.5}$ mass concentration on haze days and $14 \%$ and $31 \%$ on clear days, respectively; OC was $9.8 \mu \mathrm{g} \mathrm{m}^{-3}$, more than 2 times higher than on clean days $\left(4.0 \mu \mathrm{g} \mathrm{m}^{-3}\right)$; EC was $1.5 \mu \mathrm{g} \mathrm{m}^{-3}$, about 2 times higher than on clean days $\left(0.8 \mu \mathrm{g} \mathrm{m}^{-3}\right)$; The OC/EC ratios was elevated (6.75) during the haze period, lower values (5.07) were found during clean period. At S1, TC and water-soluble ions accounting for an average of $27 \%$ and $52 \%$ of $\mathrm{PM}_{2.5}$ mass concentration on haze days and $24 \%$ and $47 \%$ on clear days; OC was $22.1 \mu \mathrm{g} \mathrm{m}^{-3}, 1.7$ times higher than on clean days $\left(12.2 \mu \mathrm{g} \mathrm{m}^{-3}\right)$; EC was $4.1 \mu \mathrm{g} \mathrm{m}^{-3}, 1.6$ times higher than on clean days $\left(2.5 \mu \mathrm{g} \mathrm{m}^{-3}\right)$. The OC/EC ratio was 5.52 on haze days, higher than 4.87 on clean days. Guinot et al (2007) and Yao et 
al. (2016) reported that the ratios of OM/OC for urban and non-urban areas in NCP were 1.4-1.8 (1.7 in Beijing) and 2.07. As a result, OM was calculated using 1.5 times of $\mathrm{OC}$ at $\mathrm{S} 1$ site and 2.07 times of $\mathrm{OC}$ at $\mathrm{S} 2$.

Compared with S2, there were higher OC, EC and water-soluble ions concentrations and lower $\mathrm{OC} / \mathrm{EC}$ ratios at $\mathrm{S} 1$. The higher OC/EC ratio at $\mathrm{S} 2$ was correlated with the formation of secondary organic carbon at remote regions. In addition, the mass concentrations of $\mathrm{SO}_{2}, \mathrm{CO}, \mathrm{NO}_{2}$ were little higher and $\mathrm{O} 3$ is little lower on haze days than clean days at all sampling sites (Table S1).

\section{Low view of TEM images in haze days}

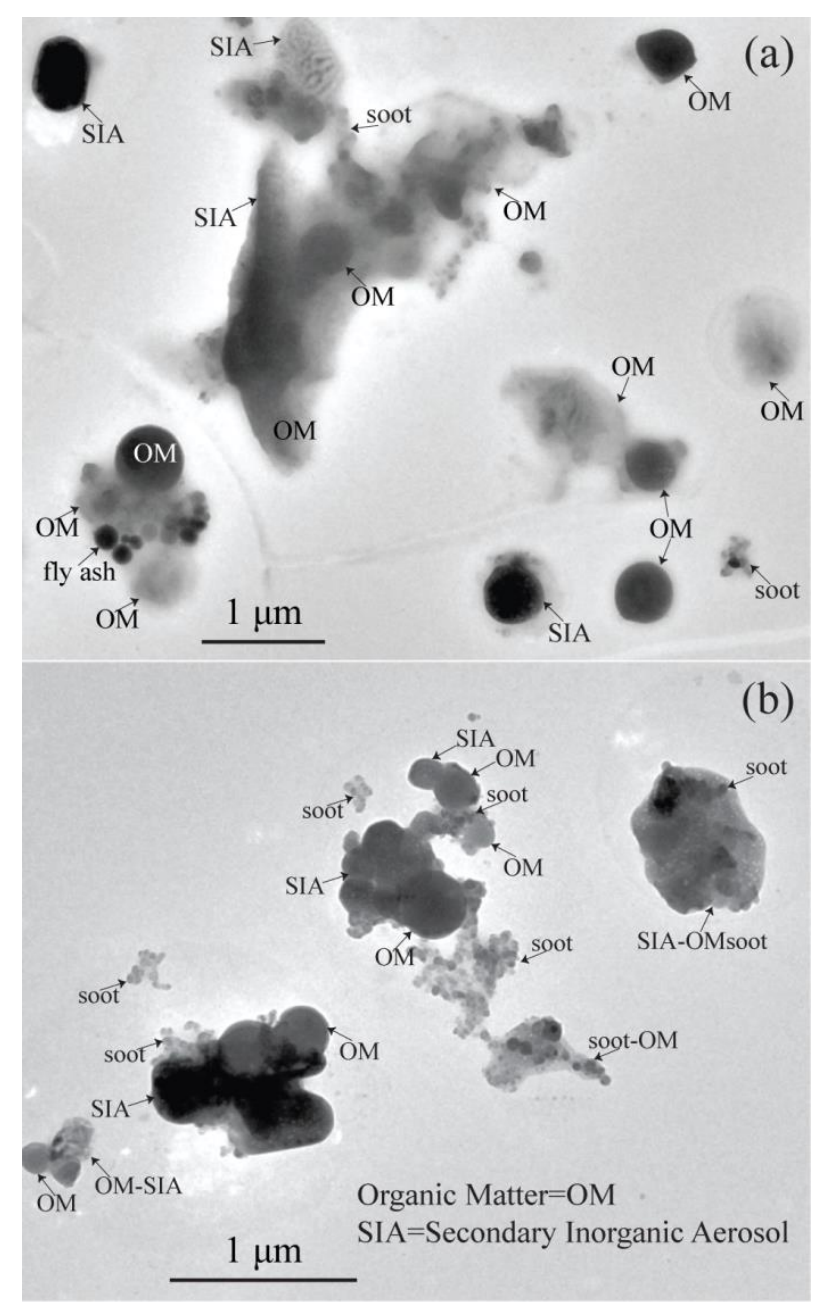

Figure S5. Individual particles during haze periods with $\mathrm{PM}_{2.5}$ mass concentration larger than $75 \mu \mathrm{g} \mathrm{m}^{-3}$. (a) low view of many particles containing elemental C collected on 15 December at S1 site. (b) low view of many particles containing elemental C collected on 18 December at S2 site. 


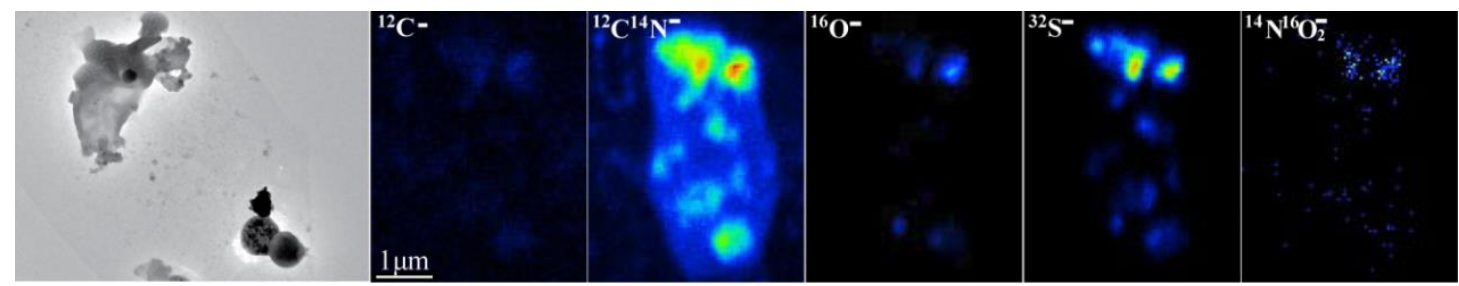

Figure S6. NanoSIMS-based ion intensity mappings of ${ }^{12} \mathrm{C}^{-},{ }^{12} \mathrm{C}^{14} \mathrm{~N}^{-},{ }^{16} \mathrm{O}^{-},{ }^{32} \mathrm{~S}$, and ${ }^{14} \mathrm{~N}^{16} \mathrm{O}_{2}^{-}$from one individual OM mixture particle.

\section{Number fractions of OM-containing particles}

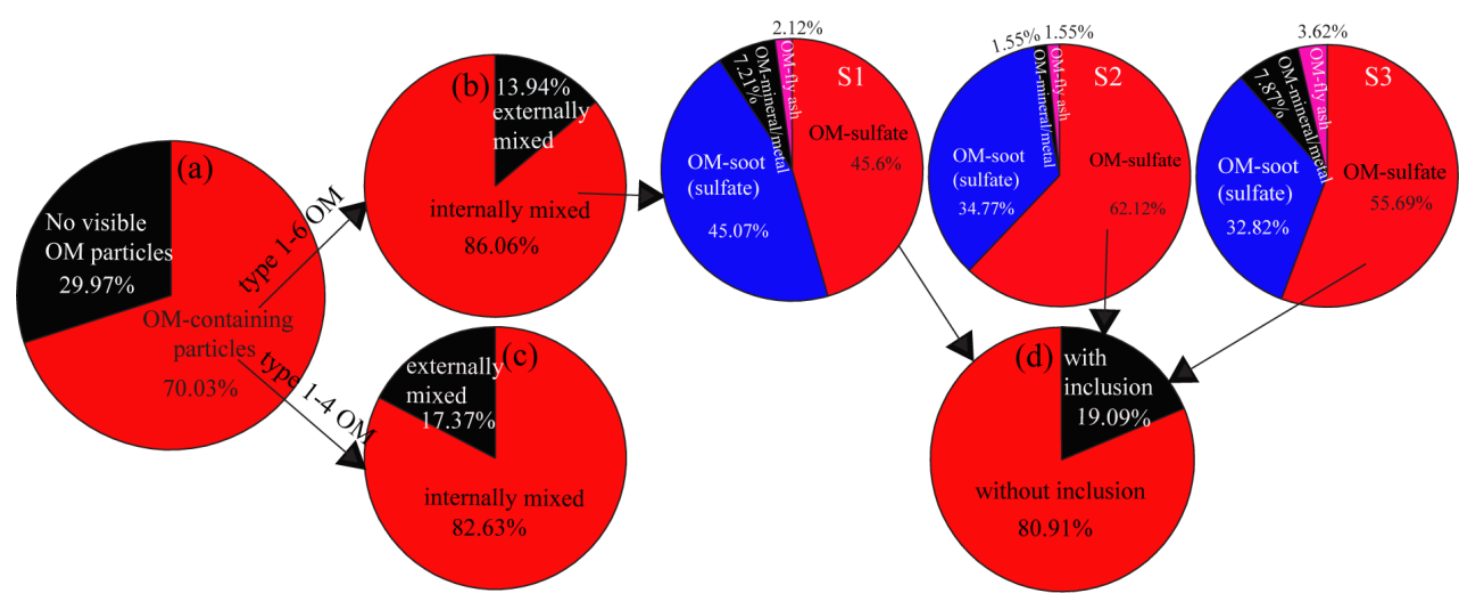

Figure S7. Number fractions of different kinds of OM-containing particles at three sites. (a) OM-containing particles and no visible OM particles of 5090 individual aerosol particles. (b) Number fraction of internally and externally of 3565 OM-containing particles. The OM internally mixtures at S1, S2, and S3 were displayed in the back of pie chart b. (c) Number fraction of internally and externally of recognizable 2365 type 1-4 OM particles. (d) Number fraction of with or without inclusions of 1687 OM-sulfate particles.

\section{Comparison of OM-soot particles in three sampling sites}




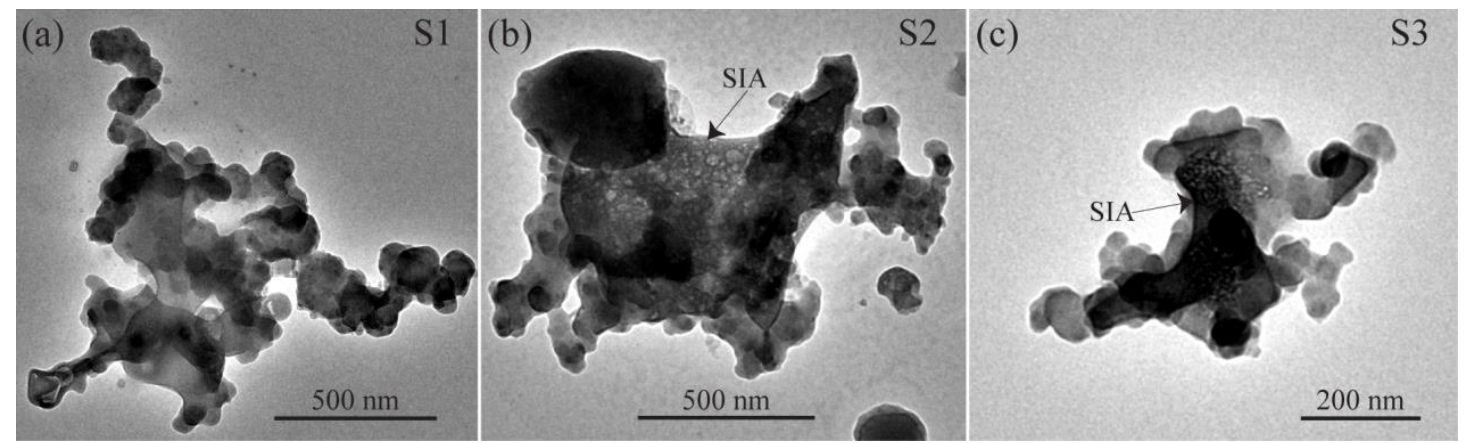

Figure S8. OM-soot particles in three sampling sites are different. (a) Exist alone and no SIA at S1 site; (b) and (c) OM-soot mixed with SIA. This is a common phenomenon during this field campaign.

\section{Comparison of $\mathrm{C}, \mathrm{O}$, and $\mathrm{Si}$ of $\mathrm{OM}$ particles from different sources}

OM aerosol particles produced by coal combustion and corn stalks were collected in lab. The elemental composition of $34 \mathrm{OM}$ particles from coal combustion and 28 OM particles from corn stalks combustion were analyzed using the EDX. The ratios of $\mathrm{Si} / \mathrm{C}$ and $\mathrm{Si} / \mathrm{O}$ in them were calculated. The same information of 281 individual OM particles in light and moderately haze samples was also obtained. The three lines represent the links between average ratios of $\mathrm{Si} / \mathrm{O}$ and $\mathrm{Si} / \mathrm{C}$ in $\mathrm{OM}$ particles. We calculated the fraction of haze OM particles with lower ratios of $\mathrm{Si} / \mathrm{O}$ and $\mathrm{Si} / \mathrm{C}$ than coal combustion, and found that $71 \%$ associated with coal line. 


\section{References}

Guinot, B., Cachier, H., and Oikonomou, K.: Geochemical perspectives from a new aerosol chemical mass closure, Atmos. Chem. Phys., 7, 1657-1670, doi:10.5194/acp-7-1657-2007, 2007.

Yao, L., Yang, L., Chen, J., Wang, X., Xue, L., Li, W., Sui, X., Wen, L., Chi, J., Zhu, Y., Zhang, J., Xu, C., Zhu, T., and Wang, W.: Characteristics of carbonaceous aerosols: Impact of biomass burning and secondary formation in summertime in a rural area of the North China Plain, Sci. Tot. Environ., 557-558, 520-530, doi:10.1016/j.scitotenv.2016.03.111, 2016. 